\title{
CLIL practice in a maritime English course: EFL students' perception
}

\author{
Nurmala Elmin Simbolon \\ Marine and Fisheries Science Department, Politeknik Negeri Pontianak, Indonesia \\ Correspondence: \\ Email: simbolon73@gmail.com
}

\begin{abstract}
This article examines to what extent 'content and language integrated learning' or CLIL approach has impact on students' learning in a Maritime English course. The graduates of Fishing Technology Study Program (TPI) in Advance University are required to have a certificate of nautical expert of fishing vessel (ANKAPIN) when applying for a job in a fishing vessel in Indonesia. One of the subjects assessed in the ANKAPIN examination is Maritime English. Bearing its name, this particular content subject consists of Maritime-related terminology and phrases. Believed as an effective way of learning a second, or a foreign language by integrating content and language learning, CLIL approach requires the collaboration between the lecturers of English and discipline subjects. The action research reported in this article implemented an English medium instruction (EMI) class using CLIL approach in an English as foreign language (EFL) context. The data collection included students' pre-test and post-test results and questionnaires of student evaluation towards CLIL classroom learning. The results of the tests were analyzed descriptively using the Excel program and the evaluation survey was with content analysis. The results of this study showed students' increased understanding of vocabulary in the field of Maritime. Students also expressed their positive experience in the CLIL class. Besides, students articulated some more to experience including authentic learning aids such as a fishing vessel and more visual materials.
\end{abstract}

Keywords: CLIL; EMI; Maritime English; ANKAPIN

$\begin{array}{llll}\text { Received: } & \text { Revised: } & \text { Accepted: } & \text { Published: } \\ \text { 30 November 2019 } & \text { 20 April 2020 } & \text { 28 August 2020 } & 31 \text { August 2020 }\end{array}$

\section{INTRODUCTION}

Global competition has triggered the importance of English proficiency among the graduates of tertiary institutions, including vocational tertiary education especially in the Association of Southeast Asian Nations, or ASEAN region. English is used as the lingua franca in ASEAN and its Qualification Reference Framework (AQRF) states the mobility of its professionals should be developed (Association of Southeast Asian Nations, 2015). In addition, the demand for undergraduate educated workers in 2030 is predicted to increase as many as three times in the last decade (Handayani, 2015). Hence, the ability to communicate with other global populations in the near future is certainly a skill that should be possessed by skilled workers. Furthermore, studying at a 
Simbolon, N.E. (2020). CLIL practice in a maritime English course: EFL students' perception. EduLite: Journal of English Education, Literature, and Culture, 5 (2), 263-276. DOI: http://dx.doi.org/10.30659/e.5.2.263-276

vocational education institution, the students of the study reported in this article are also expected to be able to communicate in English in their work field.

Many students in Indonesia including in this research context, however, have limited English skills and low motivation in learning English (Simbolon, 2015). One of the reasons for this limitation could be that English is considered as a foreign language (EFL) in Indonesia. This context contributes to limited exposure of English in society. English exists officially as a subject at high schools and universities in Indonesia. So, this study aims to examine the implementation of content and language integrated learning (CLIL), a second or additional language (L2) learning approach which integrates language learning with the student's field of expertise, namely Fishing Technology study program.

In the field of English language teaching (ELT), 'English for Specific Purposes' (ESP) is a type of ELT approach where language teaching is determined by the goals of a subject matter curriculum (Hutchinson $\&$ Waters, 1987). Similar to this approach, the term 'content and language integrated learning' (CLIL) (Stoller, 2008) is used especially in many contexts in Europe and few in Indonesia (Floris, 2014). CLIL is an educational approach that is used in many English medium instruction (EMI) classes where a dual-focus, language and content, skills are expected to achieve (Coyle, Hood, \& Marsh, 2010).

Learning motivation is closely related to CLIL practice. Its relevance to the study area of students helps student learning engagement. Furthermore, a variety of learning strategies and activities within a CLIL class may help make learning stimulating and fun (Dörnyei, 2007).

Implementing CLILL approach requires English language and content teachers to collaborate in order to capture general and specific themes in the specific expertise and skill to be delivered to the students. There are several collaboration models that can be done by lecturers in implementing this CLIL (Coyle et al, 2010). This study applies a model called the 'adjunct model' (Stoller, 2008). This is a model where the lecturers of subject matter and English courses teach the same students or class in their own subject or course. For example, the subject 'Radar Navigation' is presented by a content lecturer by introducing as much as possible using English texts about the subject. On the other side, the lecturer of English course uses the CLIL approach incorporating the topic 'Radar Navigation' theme in the purpose of improving the students' English skills. This current research focuses on the collaboration between the English lecturers with a few core subject lecturers when designing the curriculum of Maritime English course. This article specifically discusses the implementation of CLIL practice in Maritime English classroom.

To date, some studies on CLIL practice have been done and show some support for this practice. Their beliefs in the benefits of CLIL were evidence in the studies. A study conducted by Lundin \& Persson, 2015) investigated CLIL classes in Sweden and found there was improvement in student engagement and confidence when learning in CLIL practice. This positive outcome could be 
linked with the use of a range of learning resources inlcuding those from the internet. Moreover, the results of a study by McDougald (2015) found that more than half of his teacher-participants in Columbia were unfamiliar with CLIL practice. But, they believed that CLIL would benefit in improving students learning the language and the content as well.

There are several studies on student perception of CLIL classrooms which have been done as well. Lasagabaster and Doiz (2016) surveyed school students in Spain after they were introduced to CLIL classess for three years. Students perceived that there was higher improvement in their language proficiency in CLIL classess than in English classess. Another similar study was conducted by Nuñez Asomoza (2015) in a Bachelor program at a university in Mexico. The findings of their study indicated that CLIL classes were viewed positively. But students also admitted challenges of learning English in content and suggested some improvement to the teachers and learning materials.

In Indonesia, some studies on student perception of CLIL also have been done. One of them is a study by Fitriani (2016), which examined university students' learning experience in CLIL classes. Her study found that student stated that there was some improvement in their English language when learning in CLIL classess. Another study was conducted by Puspitasari (2016) in another higher education institution. Her study findings showed a positive perspective from the students, who were satisfied with a range of learning activities in the CLIL class. Collaborative tasks such as group presentation and group discussion, were believed to have contributed to this positive outcome. This study in this article had a similar focus, that is, examining student perception of CLIL practice in their Maritime English class.

This study is unique in several aspects. First, while the aforementioned studies were based on students' self-assessment on their improved learning outcomes, this current study was based on students' performance though test. Moreover, the previous studies (Nuñez Asomoza, 2015; Fitriani, 2016; Puspitasari, 2016) focused their studies on academic English. Meanwhile, this study took on a vocational study where the students were expected to be able to communicate in their work field (Fishing Technology). Furthermore, a certification examination for their expertise has been set as one of learning coutcomes for the students. Each student would take a nautical expert for a fishing vessel (ANKAPIN) examination. This certificate of competency is one of documents they provide when applying for a job in fishing industries.

This study took an action research (Carr \& Kemmis, 1986) in order to answer the following research questions: (1) How are the scores of students' pre-test and post-test of a Maritime English course? (2) What are student perceptions of the positive aspects of a CLIL class? and (3) What do the students need to experience more in a CLIL class? 
Simbolon, N.E. (2020). CLIL practice in a maritime English course: EFL students' perception. EduLite: Journal of English Education, Literature, and Culture, 5 (2), 263-276.

\section{METHOD}

\section{Research design}

An action research (Carr \& Kemmis, 1986) was undertaken at Advance University, a vocational higher education in Indonesia. It was done by giving an intervention of practising CLIL approach in a Maritime English.

\section{Research subject}

This study was conducted in a class of a Maritime English course of a threeyear Fishing Technology study program. There were 26 Semester-3 students enrolling in this course in 2019. With their technical skills, students are expected to work on fishing industries upon the completion of their study. On the last year of their study they would take a certification examination of a nautical expert (ANKAPIN). Even though it is not compulsory for them to take the examination, many students would take this examination because the certificate is one of required documents to provide when applying for a job in a fishing company. In addition to the core skills like Radar Navigation, Meteorology and Oceanography and Communication, Maritime English is a subject which is also assessed in the ANKAPIN examination.

Many of the students who enroll in this program mostly come from middle-low economic background. Some of them are from a fisherman family who live near the coast. Furthermore, some students enrolled in this study program have limited English proficiency and low learning motivation (Simbolon, 2015).

\section{Instruments}

After the research proposal was approved by the Department of Research and Community Service of the University, a set of instruments of pre-test and post-test of a Maritime English course were designed. This activity was done in collaboration with two content specialists at the study program. Using past ANKAPIN examination, the tests mostly focus on vocabulary skills. Both of the tests are provided in Appendices 1 and 2. In addition, a questionnaire with two open questions students' experience of learning in a CLIL class. The questions are written in the Indonesian language. The survey asks the students' perceptions of learning experience in a Maritime English with CLIL approach. The evaluation survey consists of two main qualitative questions reflecting Research Questions 2 and 3. They are "What are the positive aspects in CLIL practice in a Maritime English course?" and "What other aspects do you need to experience in CLIL practice in a Maritime English course?"

\section{Data collection and analysis}

Pretest was given on the first meeting of the course and posttest and the survey this were on the last meeting. There were 12 meetings in total in the Maritime English course including both tests. Students were informed regarding the research and their participation in the survey was said to be voluntary and considered as their agreement to take part in the study. Out 26 students, 24 returned the questionnaires. Data of both tests were analyzed 
EduLite Journal of English Education, Literature, and Culture Vol. 5, No. 2, August 2020, pp. 263-276 DOI: http://dx.doi.org/10.30659/e.5.2.263-276

descriptively using Excel program and content analysis was used for data from the survey on the CLIL practice at the course

\section{RESULTS AND DISCUSSION}

In the section of results and discussion, the researcher finds some key issues including the positive impacts of CLIL classes on the students' vocabulary learning. Several suggestions such as various learning materials and more practical learning experience were also stated by the students.

\section{Research question 1: How are the scores of students' pre-test and post- test of a Maritime English course?}

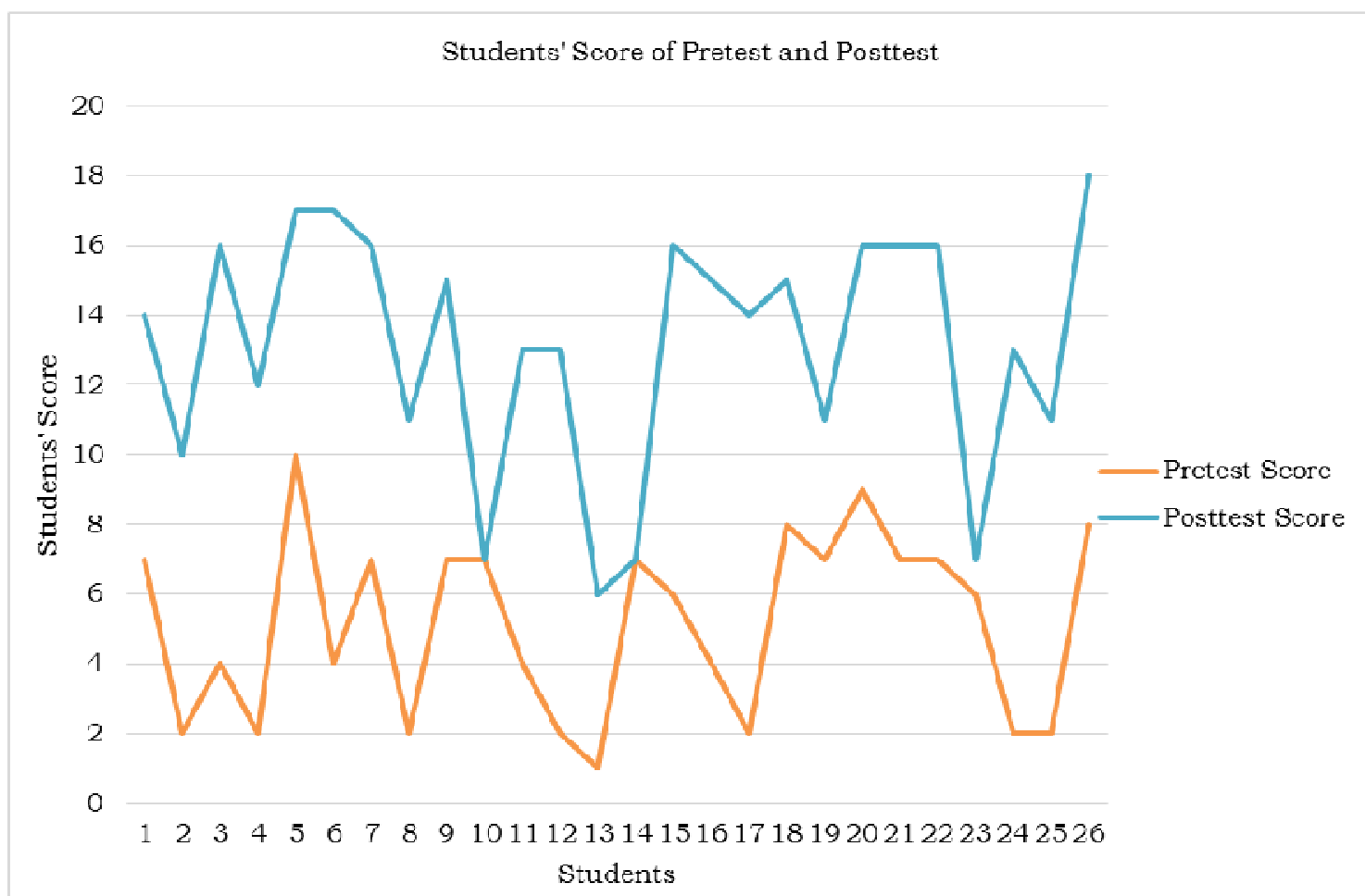

Figure 1. The scrore of students pre-test and post-test of ANKAPIN Maritime English

Table 1: Rating scale*

\begin{tabular}{cc}
\hline Score & Criteria \\
\hline $17-20$ & Excellent \\
\hline $15-16$ & Good \\
\hline $12-14$ & Fair \\
\hline $10-11$ & Poor \\
\hline $0-9$ & Very Poor \\
\hline
\end{tabular}

*The scale adopts the scoring system in the University

The findings indicated in Figure 1 suggest some points. First, there is a significant increase in the students' performance after the implementation of CLIL practice indicated in their scores of pre-test and post-test. It is worth noting Table 1 shows that the criteria of Poor and above are also categorized 
Simbolon, N.E. (2020). CLIL practice in a maritime English course: EFL students' perception. EduLite: Journal of English Education, Literature, and Culture, 5 (2), 263-276.

as the passing grades in the University learning system. The finding shows there was a compelling increase of the students' performance after learning in the CLIL practice. There was one student who reached the passing grade before the CLIL learning approach and approximately $77 \%$ of the students obtained the grades after the intervention.

Another significant figure can be seen in Student 3 as there was a four fold increase in his score. This particular finding suggests support for the findings of the previous studies (Nuñez Asomoza, 2015; Fitriani, 2016; Puspitasari, 2016; Lasagabaster \& Doiz, 2016) which showed students' perception and self-assessment on their improved learning outcomes in CLIL classes. Lastly, it is worth noting that Figure 1 that that there was no difference in the score results of Students 10 and 14 before and after the implementation of CLIL practice. There are some factors that can be linked to this finding, which could be either internal or external aspects. This result suggests incorporating interviews with the students in the future studies.

\section{Research question 2: What are student perceptions of the positive aspects of CLIL class?}

Students viewed several aspects of CLIL practice in Maritime English course in positive ways. They mentioned that the provision of learning materials in both printed and soft-file formats was helpful. In addition, they perceived they learned new vocabulary and experienced enhanced learning of content knowledge. Lastly, they enjoyed the classroom learning environment. The following figure presents students' top three most-mentioned positive aspects of CLIL practice.

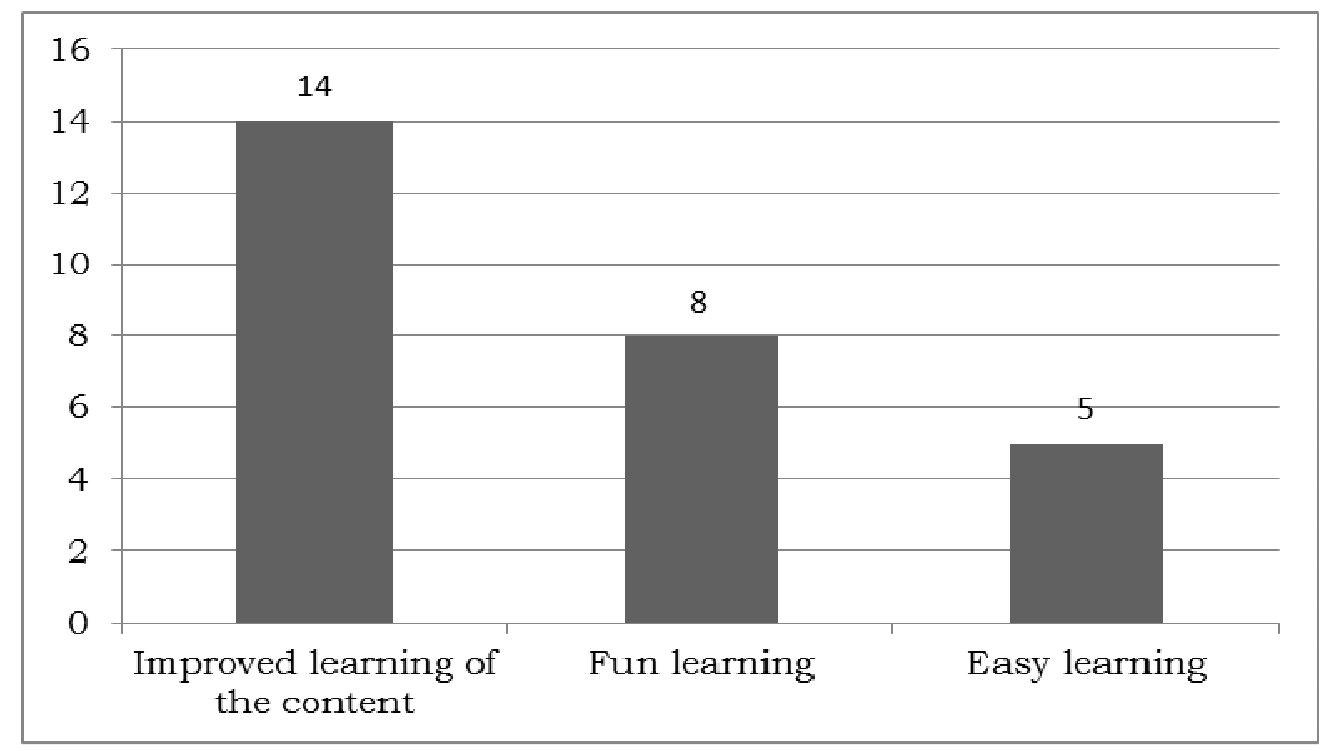

Figure 2 . Three most mentioned by students about positive aspects of CLIL practice

As can be seen in Figure 2, more than half of the students said that CLIL practice enabled them to learn more about the content knowledge. This dualfocus learning approach (Coyle et al, 2010) appears to give students access to 
EduLite Journal of English Education, Literature, and Culture

more specific terminology and knowledge about their core study. Some students expressed their voices as in the following extracts (the names are pseudonyms):

Dapat mengetahui Bahasa Inggris Kemaritiman terutama pada bahasa perkapalan seperti 'underway', dll. (Baskoro)

[(I) know Englihs for Maritime especially in the areas of a vessel like 'underway', etc] (Baskoro)

Dengan mudah mengerti bagian-bagian kapal. Banyak pengetahuan tentang pelayaran (Ferari)

[(I) understand parts of a vessel easily. (I) have more knowledge about maritime] (Ferari)

Sangat membantu dalam mengenal dasar-dasar tentang kapal dalam Bahasa Inggris. (Gery)

[It was helpful in knowing the basic knowledge about a vessel in English] (Gery)

This particular finding was linked with the findings of Fitriani's (2016) study where students perceived there was an improvement in their learning areas of study and vocabulary. The improvement in this language component (vocabulary) seems to help students obtain knowledge about the content. Thus, vocabulary learning is one key step to acquiring the content knowledge (Coyle et al, 2010).

Another important point which can also be grasped from the above figure is that the students found the learning in the CLIL class fun.

\footnotetext{
Saya mudah memahami pelajaran dan cara belajarnya asyik (Felix)

[I understood the lesson easily and the learning approach is fun] (Felix)

Dosen yang mengajar cukup asyik dalam memberikan materi pembelajaran (Aldo)

[The lecturer taught and delivered the lessons in a fun way] (Aldo)
}

Using the word 'fun' in students expressions'(Felix and Aldo) seems to be the driver for their motivation in an L2 learning as said this student this way:

Adanya kuis membuat belajar lebih semangat (Hartono)

[The quizzes motivate my learning] (Hartono)

It is also important to note that various learning activities including quizzes appears to be one strategy which needs to be incorporated in a CLIL class where students' learning motivation (Dörnyei, 2007) can be maintained. 
Simbolon, N.E. (2020). CLIL practice in a maritime English course: EFL students' perception. EduLite: Journal of English Education, Literature, and Culture, 5 (2), 263-276.

\section{Research question 3: What do the students need to experience more in CLIL class?}

Students articulated a range of issues when asked this particular question. Following is the list of students' mentions of more aspects to experience in their learning, that include some practical lessons of English subject on a ship, a variety of learning materials (visual), more speaking and listening practice and an inreased number of meetings.

These concerns are insightful and may serve a reflection of the feature of the research context. As a vocational study program, students need to experience an authenticity to the student future workplace. In this way, more visual learning aids are necessary to include in a CLIL approach. This particular issue suggests a need for professional development of the classroom teacher in designing a more various learning materials which are multi-modal. The last three issues are limited to the scheme of the research project. Within twelve meetings including both tests, it was less possible to incorporate speaking and listening practices. This result, hence, suggests a need for the implementation of multi-methods and media of learning such as classroom meetings, online materials, and self-study tasks in a CLIL practice.

\section{CONCLUSION}

This study sought to examine the student perspectives on their learning experience in a Maritime English course with CLIL approach. Using a multimethod of data analysis. the study found that there was a significant improvement in students' learning of Maritime English, especially in their vocabulary learning. In addition, CLIL practice has given the students some access to learn the content knowledge and have positive impacts on their learning in the CLIL practice. Apart from this positive outcome, students suggested some aspects to see in their future learning including more various learning materials. This study, therefore, suggests a need for professional support for the classroom lecturer when a CLIL approach is used to promote students' learning more effectively.

\section{ACKNOWLEDGEMENTS}

We would like to thank Research and Community Service Department of Politeknik Negeri Pontianak which has funded this study. The funding has made the study possible to complete in a due time.

\section{REFERENCES}

Association of Southeast Asian Nations. (2015). Asean qualifications reference framework. https://asean.org/asean-economic-community/sectoralbodies-under-the-purview-of-aem/services/asean-qualificationsreference-framework/

Bryman, A. (2008). Social research methods (3rd ed.). Oxford University Press. 
Carr, W., \& Kemmis, S. (1986). Becoming critical: Education, knowledge, and action research. London: Falmer Press.

Coyle, D., Hood, P., \& Marsh, D. (2010). CLIL: Content and language integrated learning. Cambridge University Press.

Dörnyei, Z. (2007) Creating a Motivating Classroom Environment. In: J. Cummins \& C. Davison (Eds.) International Handbook of English Language Teaching. Springer International Handbooks of Education, vol 15. Springer, Boston, MA. pp. 719-731. doi: 10.1007/978-0-38746301-8_47

Fitriani, I. (2016). Grass Roots' Voices on the CLIL Implementation in Tertiary Education. Dinamika Ilmu, $16(2), \quad 211$. https://doi.org/10.21093/di.v16i2.320

Floris, F. D. (2014). Learning subject matter through English as the medium of instruction: students' and teachers' perspectives. Asian Englishes, 16(1), 47-59. https://doi.org/10.1080/13488678.2014.884879

Handayani, T. (2015). Relevansi Lulusan Perguruan Tinggi Di Indonesia Dengan Kebutuhan Tenaga Kerja Di Era Global. Jurnal Kependudukan Indonesia, 1O(1), 53. https://doi.org/10.14203/jki.v10i1.57

Hutchinson, T., \& Waters, A. (1987). English for Specific Purposes: A learning centred approach. Cambridge University Press.

Lasagabaster, D., \& Doiz, A. (2016). CLIL students' perceptions of their language learning process: delving into self-perceived improvement and instructional preferences. Language Awareness, 25(1-2), 110-126. https://doi.org/10.1080/09658416.2015.1122019

Lundin, C., \& Persson, L. (2015). Advantages and Challenges. Information Systems, $1-43$. http://muep.mau.se/bitstream/handle/2043/18728/LundinPersson201 5Final.pdf? sequence $=2 \&$ is Allowed $=y$

McDougald, J. S. (2015). Teachers' attitudes, perceptions and experiences in CLIL: A look at content and language. Colombian Applied Linguistics Journal, $17(1)$

25. https://doi.org/10.14483/udistrital.jour.calj.2015.1.a02

Nuñez Asomoza, A. (2015). Students' Perceptions of the Impact of CLIL in a Mexican BA Program. PROFILE Issues in Teachers' Professional Development, $17(2)$, https://doi.org/10.15446/profile.v17n2.47065

111-124.

Puspitasari, E. (2016). Classroom Activities in Content and Language Integrated Learning. Journal of Foreign Languange Teaching and Learning, 1(2), 1-13. https://doi.org/10.18196/ftl.129

Simbolon, N. E. (2015). Using the CBI method in teaching English in an Indonesian University. Pertanika Journal of Social Sciences and Humanities, 23(4), 1211-1224. 
Simbolon, N.E. (2020). CLIL practice in a maritime English course: EFL students' perception. EduLite: Journal of English Education, Literature, and Culture, 5 (2), 263-276.

Stoller, F., L. (2008). Content-based instruction. In N. Van Deusen-Scholl \& N. Hornberger (Eds.), Encyclopedia of language and education. Vol. 4: Second and foreign language education. Springer International Publishing. 


\section{APPENDIX 1}

\section{Pre-test}

\section{Choose the correct answer}

1. A boat propelled by wind:
a. Sail boat
b. motor boat
c. sailor
d. fishing boat

2. A very strong wind:
a. Windlass
b. gale
c. gantry
d. gangway

3. A landing pier is ....
a. deck
b. Jetty
c. platform
d. harbor master

4. Helmsman:
a. quarter master
b. harbor master
c. quay
d. chief officer

5. Identifying the vessel:
a. LOA
b. stern
c. flag state
d. call sign

6. In the middle part of the ship is ....
a. anchor
b. alongside
c. amidships
d. angle

7. The shortest passing distance is :
a. $\mathrm{CMG}$
b. crash
c. $\mathrm{COW}$
d. CPA

8. A device for putting out fires is :
a. fairlead
b. extinguisher
c. ETB
d. exhaust

9. To pull a vessel off after grounding:
a. Rendezvous
b. seamark
c. recover
d. refloat

10.A strong post on the quay for mooring is....
a. Bollard
b. bolt
c. bore
d. bulk

11.An area within define limits is ...
a. traffic lane
b. VTS
c. traffic clearance
d. TSS 
Simbolon, N.E. (2020). CLIL practice in a maritime English course: EFL students' perception. EduLite: Journal of English Education, Literature, and Culture, 5 (2), 263-276.

12. Maximum working load of lifting equipment that should not be exceeded is...
a. SWL
b. ITZ
c. SART
d. TSS

13. Uncontrolled movement at sea under the influence of current, tide or wind is :
a. backing of wind
b. air draft
c. adrift
d. capsize

14. Position at which a vessel required to report is ....
a. Receiving point
b. reporting point
c. reference line
d. waypoint

15. Draft is...
a. a sea mark
b. indication how deep it is from water line
c. part of engine
d. moving of an anchor

16. Navigable part of a waterway is ....
a. fairway
b. windward
c. underway
d. veering

17.A small vessel design for towing and helping large ship:
a. tanker
b. fishing vessel
c. tug boat
d. bulk carrier

18. Orders of the Master to the OOW is :
a. stand clear
b. stand on
c. segregation
d. standing orders

19. An object which blocks a fairway is ...
a. Moor
b. obstruction
c. muster
d. scene

20. Any of the floors of a ship:
a. Ladder
b. deck
c. wheel house
d. forecastle 


\section{APPENDIX 2}

\section{Post-test}

\section{Choose the correct answer}

1. Position at which a vessel is required to report is:
a. receiving point
b. reference line
c. reporting point
d. way point

2. “ obstruction in the fairway:
a. advice
b. instruction
c. information
d. warning

3. Helmsman:
a. quarter master
b. harbor master
c. quay
d. chief officer

4. A vertical partition walls which subdivide the ship interior into watertight compartments
a. bulkheads
b. watertight
c. anchoring
d. underwater

5. In the middle part of the ship is ....
a. anchor
b. alongside
c. amidships
d. angle

6. Floating without clearly determinable direction is :
a. embark
b. adjacent
b. c. afloat
d. adrift

7. The shortest passing distance is:
a. $\mathrm{CMG}$
b. crash
c. $\mathrm{COW}$
d. CPA

8. A device for putting out fires is:
a. fairlead
b. extinguisher
c. ETB
d. exhaust

9. The fore part at the ship is:
a. bulk
b. bottom
c. bow
d. brash

10. Maximum working load of lifting equipment that should not be exceeded is...
a. SWL
b. ITZ
c. SART
d. TSS

11. Main control position of a ship from which it is controlled and navigated is ...... 
Simbolon, N.E. (2020). CLIL practice in a maritime English course: EFL students' perception. EduLite: Journal of English Education, Literature, and Culture, 5 (2), 263-276.
a. galley
b. storeroom
b. c. mess room
d. bridge

12. Fishing master is...
a. commander of a vessel
b. chief of fishing operation
c. captain
d. helmsman

13. Are you under way?
a. I am not under way
c. Yes, I am under way
b. Yes, under way
d. Yes, I am

14.Uncontrolled movement at sea under the influence of current, tide or wind is:
a. backing of wind
b. air draft
c. adrift
d. capsize

15. Calculating, or estimating the ship position
a. RDF
b. Dead reckoning
b. Charts

16. Draft is...
a. a sea mark
c. part of engine
b. indication how deep it is from water line
d. moving of an anchor

17.Is the fire under control?
a. Yes, under control
b. under control
c. No, it is
d. No. the fire is not under control

18. Navigable part of a waterway is ....
a. fairway
b. windward
b. underway
d. veering

19. A small vessel design for towing and helping large ship:
a. tanker
b. fishing vessel
c. tug boat
d. bulk carrier

20. Orders of the Master to the OOW is:
a. stand clear
b. stand on
c. segregation
d. standing orders 